\title{
A Research on Relationship Between Latent Aging and Chronic Lymphocytic Thyroiditis
}

\author{
Fahri Özsungur* \\ Adana Science and Technology University and Osmaniye Korkutata University, Turkey
}

*Corresponding author: Fahri Özsungur, Adana Science and Technology University and Osmaniye Korkutata University, Adana

Chamber of Commerce Karasoku Abidinpasa st. 2201010 Seyhan, Adana, Turkey

ARTICLE INFO

Received: 幽 December 07, 2019

Published: 慧 December 12, 2019

Citation: Fahri Özsungur. A Research on Relationship Between Latent Aging and Chronic Lymphocytic Thyroiditis. Biomed J Sci \& Tech Res 23(5)-2019. BJSTR. MS.ID.003964.

Abbreviations: CLT: Chronic Lymphocytic Thyroiditis; SLE: Systemic Lupus Erythematosus

\section{ABSTRACT}

Objectives: It was aimed to determine the relationship between CLT and latent aging, in this study.

Methods: This study was conducted in November 2019 with 63 CLT patients (57 female, 6 males; living in the province of Adana in Turkey; ages ranging between 31 to 58; who responded "yes" to questions Q1 and Q2.).

Results: In this study, it was found that the physical (sallow skin, under-eye swelling, puffiness) and psychological (depression, anxiety, dysmnesia, focus problem) changes and effects taking place in the individual's body were effective in the sense of latent aging.

Conclusion: In this study, Chronic Lymphocytic Thyroiditis (CLT) was found to be associated with latent aging in the context of psychological and physical effects, and the imitation ability of latent aging via CLT was proved.

Keywords: Chronic Lymphocytic Thyroiditis; Latent Aging; Systemic Lupus Erythematosus; Autoimmune Diseases; Gerontology

\section{Introduction}

Chronic Lymphocytic Thyroiditis (CLT), known as Hashimoto's thyroiditis, is a type of disease in which the body produces high levels of anti-TPO and anti-thyroglobulin for the destruction of the thyroid gland, causing the immune system to attack healthy cells and reduce thyroid gland secretion [1]. Thanks to these antibodies, the thyroid gland shrinks, and hormone deficiency occurs. Clinical manifestations Symptoms of chronic lymphocytic thyroiditis have been found to be poor concentration, slow motion, skin discoloration, depression, irritability, menstrual dysfunction, dysmnesia [2-4]. Genetic factors, Rheumatoid Arthritis, Systemic Lupus Erythematosus (SLE) are among the risk groups in this disease. Females are eight times more likely to face this disease than males [5-7]. The fact that the findings of the disease affect the quality of life at a high level is especially important for the aging of women [8]. Latent aging is the internalization of environmental factors, experience, and knowledge related to aging and the perception that the individual enters the aging process as a result of the cognitive process [9]. In latent aging, an individual feel old even though he or she does not age and starts to be under the influence of aging. Latent aging was first introduced by Özsungur [9]. This subject, which is new in the literature, is a type of disease observed especially in autoimmune diseases. The relationship between latent aging and CLT has not been previously investigated. The aim of this study is to determine the relationship between CLT and latent aging and to contribute to the literature in this context.

\section{Materials and Methods}

This study was conducted in November 2019 with 63 CLT patients (57 female, 6 males; living in the province of Adana in Turkey; ages ranging between 31 to 58; who responded "yes» to questions Q1 and Q2.). Structured questions were taken from Özsungur [9]. The consent form was obtained from the participants. Medical reports of 63 patients about their diseases were examined. 
According to the reports, 63 participants were found to be CLT patients. The treatment recommendations and other diseases mentioned in the report findings were compared.

\section{Results}

CLT patients experience internal-oriented psychological problems. The participants associated the external stimuli with age perception less than other factors. In particular, the physical (sallow skin, under-eye swelling, puffiness) and psychological (depression, anxiety, dysmnesia, focus problem) changes and effects taking place in the individual's body were effective in the sense of latent aging. Cognitive learning 1 (associating physical changes with aging), cognitive learning 2 (associating diseases and pain perception with aging) and medically obligatory drug dependence were effective on the perception of latent aging. Medical effects of latent aging were CLT, SLE and other diseases (Cardiac diseases, blood cholesterol). Social effects of latent aging are reported by the participants as «withdrawal from social activities» and «feeling excluded from society». The imitation level of latent aging (diseases) was determined as Alzheimer's disease, dementia, cancer, CLT and SLE (Table 1). Besides, CLT can cause negative social consequences due to the deterioration of mobility. This decline is perceived by the participants' friends as the effect of aging syndrome.

Table 1: Case report results.

\begin{tabular}{|c|c|c|c|c|c|c|}
\hline $\mathbf{Q}$ & $\begin{array}{l}\text { Q3:Perception of latent } \\
\text { aging }\end{array}$ & $\begin{array}{l}\text { Q4:Sense of latent } \\
\text { aging }\end{array}$ & $\begin{array}{c}\text { Q5:Perception of the } \\
\text { individual effects of latent } \\
\text { aging }\end{array}$ & $\begin{array}{l}\text { Q6: Medical effects } \\
\text { of latent aging }\end{array}$ & $\begin{array}{l}\text { Q7:Social effects of } \\
\text { latent aging }\end{array}$ & $\begin{array}{l}\text { Q8:The imitation } \\
\text { level of latent aging }\end{array}$ \\
\hline RC1 & $\begin{array}{l}\text { Cognitive learning } 2 \\
\text { (associating diseases } \\
\text { and pain perception } \\
\text { with aging) }\end{array}$ & $\begin{array}{l}\text { Psychological } \\
\text { effects (depression, } \\
\text { anxiety, dysmnesia, } \\
\text { focus problem) }\end{array}$ & $\begin{array}{c}\text { Psychological } \\
\text { consequences (Burnout, } \\
\text { loneliness, asociality, } \\
\text { introversion) }\end{array}$ & CLT & $\begin{array}{l}\text { Withdrawal from } \\
\text { social activities }\end{array}$ & $\begin{array}{l}\text { Alzheimer's disease, } \\
\text { dementia, cancer }\end{array}$ \\
\hline f & 34 & 38 & 30 & 53 & 39 & 33 \\
\hline$\%$ & 53.96 & 60.31 & 47.62 & 84.13 & 61.91 & 52.38 \\
\hline RC2 & $\begin{array}{l}\text { Cognitive learning } 1 \\
\text { (associating physical } \\
\text { changes with aging) }\end{array}$ & $\begin{array}{l}\text { physical (sallow } \\
\text { skin, under-eye } \\
\text { swelling, puffiness) }\end{array}$ & Fatigue, unjustified pain & SLE & $\begin{array}{l}\text { Feeling excluded } \\
\text { from society }\end{array}$ & CLT \\
\hline f & 21 & 25 & 11 & 6 & 20 & 20 \\
\hline$\%$ & 33.33 & 39.69 & 17.46 & 9.52 & 31.74 & 31.74 \\
\hline RC3 & $\begin{array}{l}\text { medically obligatory } \\
\text { drug dependence }\end{array}$ & - & $\begin{array}{l}\text { Stress, anxiety, } \\
\text { nervousness }\end{array}$ & $\begin{array}{l}\text { Cardiac diseases, } \\
\text { blood cholesterol }\end{array}$ & No change & SLE \\
\hline f & 8 & & 22 & 4 & 4 & 10 \\
\hline$\%$ & 12.71 & & 34.92 & 6.35 & 6.35 & 15.88 \\
\hline
\end{tabular}

Note: Q: Question; RC: Response Coding; 63 (57 females, 6 males); Q: Question; R: Response; f: Frequency

\section{Discussion}

According to the research findings, CLT has psychological and physical effects that cause the perception of aging at the cognitive level. Psychological and physical symptoms that occur in the body are the subjects that patients take into consideration in their perception of aging. These patients are under the influence of autoimmune diseases. Symptoms of SLE patients with similar symptoms are internalized in the cognitive context. CLT patients' perception of aging is less affected by changes in their environment. CLT patients are affected by the aging symptoms of other CLT and SLE patients around them. This demonstrates the imitation ability of latent aging. There is no study on this subject in the literature. Vacante et al. [10] revealed the comparability of thyroid-related symptoms with the physiological signs of the aging process in their literature review study. Aggarwal and Razvi [11] also proved this approach. On the other hand, studies revealed the relationship between CLT and SLE [10-14]. However, these studies have not been able to determine that CLT may cause latent aging by causing the perception of aging. The perceptual dimension and imitation ability of aging are not studied in the literature. For future studies, it is recommended to investigate the relationship of autoimmune diseases with the perception of aging and imitation abilities in the context of aging Figure 1. This study has some limitations. The fact that the participants consist mainly of women limits the generalizability of the results. It is also recommended that the study be clinically tested. 


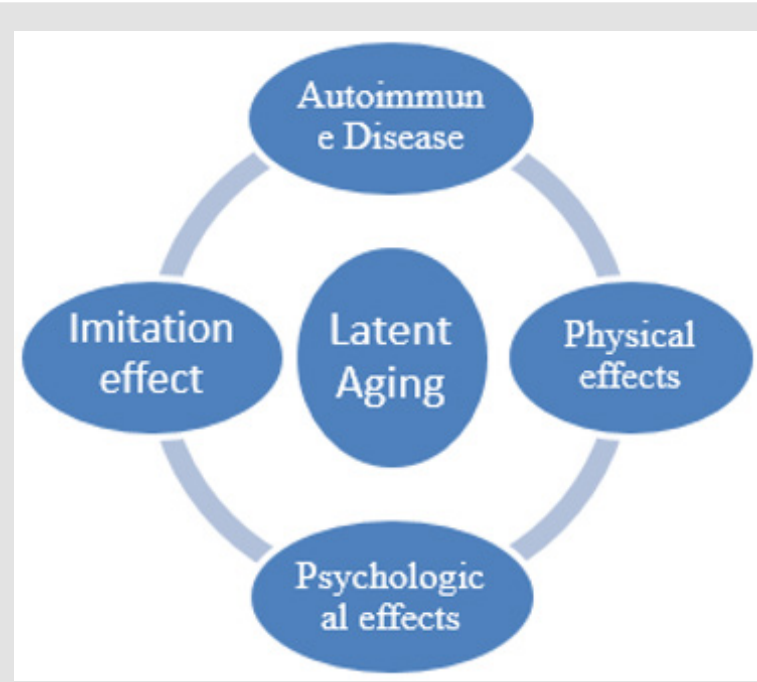

Figure 1: Latent aging cycle.

\section{Conclusion}

In this study, Chronic Lymphocytic Thyroiditis (CLT) was found to be associated with latent aging in the context of psychological and physical effects, and the imitation ability of latent aging via CLT was proved.

\section{References}

1. Holm LE, Blomgren H, Löwhagen T (1985) Cancer risks in patients with chronic lymphocytic thyroiditis. New England Journal of Medicine 312(10): 601-604.

2. Rallison ML, Keating FR, Tyler FH (1975) Occurrence and natural history of chronic lymphocytic thyroiditis in childhood. The Journal of pediatrics 86(5): 675-682.

\section{ISSN: 2574-1241}

DOI: 10.26717/BJSTR.2019.23.003964

Fahri Özsungur. Biomed J Sci \& Tech Res

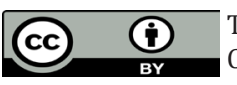

This work is licensed under Creative Commons Attribution 4.0 License

Submission Link: https://biomedres.us/submit-manuscript.php
3. Kebebew E, Treseler PA, Ituarte PH, Clark OH (2001) Coexisting chronic lymphocytic thyroiditis and papillary thyroid cancer revisited. World journal of surgery 25(5): 632-637.

4. Tamimi DM (2002) The association between chronic lymphocytic thyroiditis and thyroid tumors. International Journal of Surgical Pathology 10(2): 141-146.

5. Gluck FB, Nusynowitz ML, Plymate S (1975) Chronic lymphocytic thyroiditis, thyrotoxicosis, and low radioactive iodine uptake: Report of four cases. New England Journal of Medicine 293(13): 624-628.

6. Ott RA, McCall AR, McHenry C, Jarosz H, Armin A, et al. (1987) The incidence of thyroid carcinoma in Hashimoto's thyroiditis. The American surgeon 53(8): 442-445.

7. Giordano C, Stassi G, De Maria R, Todaro M, Richiusa P, et al. (1997) Potential involvement of Fas and its ligand in the pathogenesis of Hashimoto's thyroiditis. Science 275(5302): 960-963.

8. Hayashi N, Tamaki N, Konishi J, Yonekura Y, Senda M, et al. (1986) Sonography of Hashimoto's thyroiditis. Journal of Clinical Ultrasound 14(2): 123-126.

9. Özsungur F (2019) Latent Aging. Biomedical Journal of Scientific \& Technical Research (BJSTR) 20(4).

10. Vacante M, Biondi A, Basile F, Ciuni R, Luca S, et al. (2019) Hypothyroidism as a Predictor of Surgical Outcomes in the Elderly. Frontiers in endocrinology 10: 258.

11. Aggarwal N, Razvi S (2013) Thyroid and aging or the aging thyroid? An evidence-based analysis of the literature. J Thyroid Res 2013: 481287.

12. Latif S, Jamal A, Memon I, Yasmeen S, Tresa V, et al. (2010) Multiple autoimmune syndrome: Hashimoto's thyroiditis, coeliac disease and systemic lupus erythematosus (SLE). JPMA-Journal of the Pakistan Medical Association 60(10): 863.

13. Lin WY, Chang CL, Fu LS, Lin CH, Lin HK, et al. (2015) Systemic lupus erythematosus and thyroid disease: A 10-year study. Journal of Microbiology, Immunology and Infection 48(6): 676-683.

14. Shimizu M, Hirokawa M, Manabe T, Shimozuma K, Sonoo H, et al. (1997) Lithium associated autoimmune thyroiditis. Journal of clinical pathology 50(2): 172-174

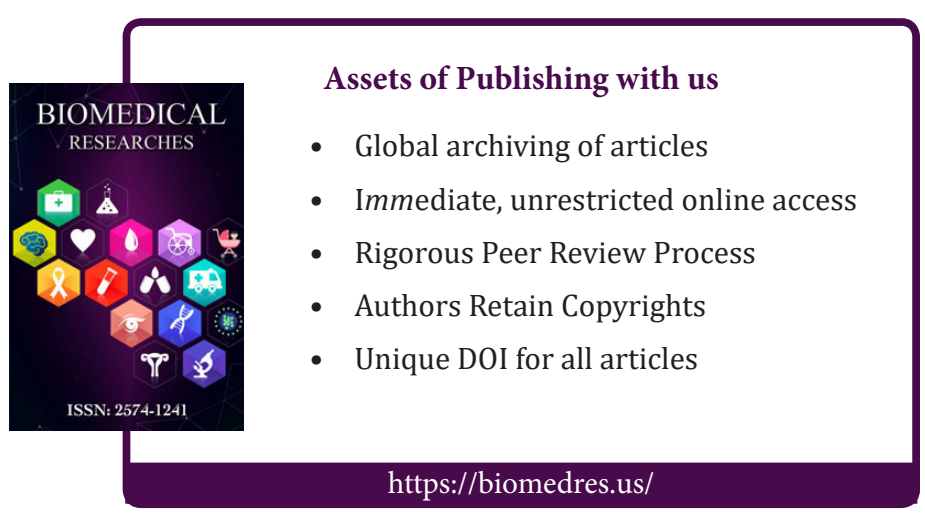

